\title{
Homo Democraticus and Homo Philosophicus - Epistemological View on Teaching Philosophy in the Public Schools in Albania
}

\author{
Arben Haxhiymeri \\ Department of Civic education, Faculty of Education Sciences \\ University "A.Xhuvani", Elbasan, Albania
}

\section{Doi:10.5901/mjss.2015.v6n2s5p64}

\begin{abstract}
The educational system in Albanian has gone through many substantial changes and very challenging times over the last two decades. The majority of these changes were, without doubt, dictated by the very insistent endeavor to bring the Albanian educational system closer to the European one. After a very succinct, but concise description, of the changes the basic concepts of education were gone through, and of developmental strategies of the Albanian Educational Reform from 1992 to the present, in this paper we give a very brief account of the ideas and considerations the Albanian policymakers and other decision-making organs share about philosophy and its role in our times, as well as of the status and the place philosophy as part of the academic curriculum holds presently among, and compared to other fields of knowledge and culture. In this paper we present then our considerations and arguments on philosophy and on philosophizing, its nature and its importance to the human thinking, knowledge, and civic education, as well as the relation that has with democracy, freedom, the free individuals and the free society. Our paper aims to sensitize the community of teachers, of professionals and more specifically, the community of policymakers and decision-makers, to the vital importance philosophy has for the human life and existence, as well as to foster this last community to stop its actual attitude - which consists in sacrificing philosophy in the name of a mentality that has since long become part of the past - and to start its engagement for the creation of the necessary spaces and conditions to philosophy, by giving it the very place it deserves among other disciplines of academic curriculum. This is, at least, what the contemporary experience of other European countries is dictating us with more insistence than ever.
\end{abstract}

Keywords: homo democraticus, homo philosophicus, philosophy and curriculum of education, individual and liberty, teaching sciences and teaching humanities.

\section{Introduction}

In 2010, aiming to offer a very small and modest contribution to enriching the library of philosophical thought in the Albanian language and to responding, at the same time, to the very needs of that category of students that study the subject of philosophy as part of their academic curriculum, we rendered in Albanian two works written from two wellknown authors of the XX century: "Way to Wisdom", of Karl Jaspers, and "What does it all mean?", of Thomas Nagel.

Despite the differences, they both claim the idea that man is a natural philosopher, that philosophy is intrinsic to him, whether he was caught or not, adult, child or adolescent. "The philosophical thinking is always with us and within us", writes Jaspers, as he tries to highlight this as a feature of every human being. He repurposes this concept in the last chapter of his book, adding that "the philosophical thinking is in some form omnipresent wherever there are men" (Jaspers, 2010).

Within the same perspective could be easily accommodated Karl Popper as well, which is neither a neo-positivist, nor an existentialist (as we often consider Jaspers, separating his philosophy from any other ideology or ism). In difference from many other contemporary philosophers, K. Popper claims and argues that more or less all the human beings are philosophers, in as much as all human beings have an idea about life and death, about the way we should live our life, and so on (Popper, 1994).

We see that the authors who are concerned to know the human entity, what is man, seem being not satisfied with the "zoo politikon" of Aristotle, nor with the definitions of homo sapient, homo farber or homo aestheticus of Luc Ferry; they seem unsatisfied either with the 'intentionality' of F. Nietzsche as an essential trait of man, nor with the "faculty to project" formulated by J. P. Sartre, in "Existentialism is a Humanism". Man, maybe they want to say, is characterized by the ability to philosophize. In that case we will have a "zoo philosophikon" or a "homo philosophicus" (Haxhiymeri, 2010).

The man in his lifetime is realized as a philosopher, the question is whether this is accomplished at an instinctive level or rises at a theoretical level. In our opinion the concern of the authors is growing this capacity, common to every 
person, not only to a certain elite. Seen from this perspective, the development of the ability to philosophize and exercise of such skills is not a strictly private matter or a game of desires; almost become a social issue, a fundamental human right, an obligation and a civic duty, a condition of human life. Such a community would appear as a human society. This effort is realized and intrinsic to the development of channels that grow and in turn develop the ability to philosophize attacking at the same time the cynicism and prejudice of those who look to philosophy as a characteristic of the so-called elitist minds. The mystification of philosophy and science, photogenic and hermeticism of philosophical communication become criticized issues in the works of these authors.

Karl Popper explains that every intellectual has specific responsibility, because it has the opportunity and the privilege of studying, for these reasons, has to give to society, the representation of his studies in a simple, clear and modest way and not seek in every way to impress with the philosophy. Popper continues, saying that "Anyone who cannot speak simply and clearly should say nothing and continue to work until he can do so" (Popper, 1994).

Projecting this topic in the reality of our work, I would not think that any negligence, fear or distrust, towards, philosophy during these twenty years expresses a critical assessment of Albanians academic ability, the ability or inability to present in those simple forms suggested by Popper, or to deal exclusively with matters not digestible, which have a metaphysical nature, sophistry, syllogisms and logic aporias. The last two decades of the post-communist transition were more than enough to prepare not indoctrinated philosophers and/or specialists in various academic fields. Philosophers of education, philosophers of science, history, law, etc., ought to have been prepared these years, drafting and implement supportive policies. In the same way it is also in the field of philosophical education. The redevelopment of graduates in philosophy in our universities, of teachers in service in this discipline, would be in any case a better solution that detachment from philosophy or even worse the elimination of this discipline.

However, let's dedicate a space to the argument that sees philosophy as man's existential need and feature of free citizen in a democratic society.

Such a feature as the ability to philosophize, as well as to write or to think logically and theoretical is a product of education. As indeed we know from studies in the field of developmental psychology, cognitive psychology and other disciplines even more specific, such as psychology of reason, the psychology of morality etc., with the birth and development of the capacity of logical thinking and with the subsequent development of sociality, of affective components etc., the teenagers develop capacity of philosophical meditation and philosophical game, the discussion or dialogue (even Socratic), algorithmic issues and other capacity of different natures. This is the age to start, assisting and supporting this process. Thomas Nagel says that the beginnings of thinking about the world around us emerge during the fourteenth year of age, when "... many people start to think about philosophical problems on their own ..." (Nagel, 1987).

In this sense: „... the philosophical raw material comes directly from the world and our relation to it, not from writings of the past" (Nagel, Ibidem).

Do we have adequate curricula to respond in a timely and appropriate manner to the developmental needs of this generation? What is the way to obtain philosophical culture by people belonging to different levels of education?

Of course, for this, we must bring the attention to the fact that any consideration and evaluation needs a specific methodology, for some data on what we will evaluate, and tools with which we will measure or estimate our object of study and configuration types that serves to compare and measure it.

Let's take a quick presentation or a synopsis of the fate of philosophy in public education in Albania since the '90s. Teaching Marxist-Leninist philosophy was exchanged with History of Philosophy (Under a Marxist interpretation, or at best, looking for an impartial revaluation of philosophical culture, of course, teachers and lecturers were the same of the ' 80 s, both in mentality and tools used for knowledge and for the philosophical interpretation).

After 1992, in a school year of the second cycle of education would have been done a philosophical discipline, namely, an Introduction to the Philosophy and something from the History of philosophy. Originally was published a text, a very good adaptation from a European school text, but it proved somewhat difficult for students. The text that was published later, as good as the first, was used for more than a decade. Department of Philosophy at the University of Tirana, in the context of educational reform had become almost inexistent. The only Institution which was entrusted to prepare teachers and specialists of philosophy was not working, and in the same way was not working for the retraining of teachers in service. A large part of the department lecturers, were converted to sociologists. Sociology became favorite discipline, in vogue for several faculties and separate branches, while in most of these courses philosophy was eliminated, even as the philosophy of scientific knowledge or of a particular science. The same thing happened in the University of Elbasan: the course of the study of biochemistry is not performed since that time any philosophical discipline (even no training courses for citizenship); in Mathematics and Physics branch until 2001 was conducted Philosophy of Mathematics and Philosophy of Physics, but later they were eliminated from the program. In Scientific Masters programs can be found rarely a philosophical discipline (Philosophy of language, the MSc in Linguistics; Philosophy of History, Msc 
in Cultural Heritage, ...) and almost none such in doctoral programs.

Not a good situation for philosophy was deteriorated even further with the implementation of the New Curriculum (2009-2010) for high school, where Philosophy becomes an optional subject matter. From 3240 hours of teaching in classes X, XI, XII, 2628 hours of teaching belong to programmed teaching and 360 hours are reserved for compulsory optional subject (Of these, 120 hours are for class XII). The students must choose between the following cases, two of them and each with 2 hours / week: foreign language, Albanian language and literature, mathematics, cultural heritage, philosophy, history, economics, chemistry, physics, biology. Philosophy is confronted with the disciplines that have a considerable space, not only in curriculla of the first cycle of compulsory education, which lasts for nine years, but also in the cycle of high school that lasts three years: foreign Languages, albanian language and literature, mathematics in 3 years with 3 hours / week; history, in 3 years with 1/2/2 hours / week; chemistry, physics and biology, in class X and XI, with 2 hours / week, etc. (Kfr. The Institute of Curricula and Training, 2009).

This picture would still be incomprehensible unless we keep in mind the guidelines for the development of new curricula of high school (ICT - Institute of Curricula and Training) and in particular the clause that says, "The school has an obligation to provide to each student: [...] The school hours belonging to the optional subject matter for each high school class", and further, that, "The school could not offer to students: [...] all the other subjects of compulsory curricula" (The Institute of Curricula and Training, 2009).

The meaning of the text mentioned above, noting with regret, is an ornamental embellishment of public high school curricula with courses that will not take place in most of these institutions.

Among them, the worst fate will be reserved for philosophy, for some special reason, subject of Philosophy will not be carried out, although some students may choose it. High school teaching staff will not contain any specialist in this field (or in the worst cases, will be executed by teachers who have no competence in it).

We would not like to compare this initiative of our educational institutions with the imperial decree from Justinian in 529 A.D., which prohibited the teaching of philosophy, law and literature in Athens. There will not comfort us nor any expert reminding that such things have happened elsewhere, or that in these countries is not taught at all philosophy. We live in a wild season with prejudice, or better yet, in a season full of exclusionary and hostile actions against philosophy. But we care about how people react, intellectuals, too. In fact, to them, we want remember the major events in France, the creation of "General Staff of philosophy" (Etats Généraux de la Philosophie), in 1979, when about 1,200 philosophers and teachers of philosophy from around the world responded unequivocally and unanimously to the call made by Jacques Derrida to protest the French parliament that those days had passed a law that denied the right philosophy to be part of the high school program in the territory of the French Republic" (Haxhiymeri, 2010).

Few years before Th. Nagel published his book titled "What does it all mean?", several education specialists and researchers in the USA were expressed with concern about "[...]... The non-inclusion of philosophy as an integral part of American educational program, [...] its omission from high school programs"... (with the reason that) [...] this is a college subject", or because "...it is very advanced for the level of middle school."; its exclusion in high school programs with the argument that it is "irrelevant" and "that there develops critical thinking" (Breslin, 1982).

Apparently Thomas Nagel, presents conclusions from a broader perspective in his book, when he writes: „People ordinarily study philosophy only when they go to college" (Nagel, 1987).

Studying the school curricula of several countries and seeing their development and differences, we note that the inclusion of Philosophy in high school curricula has different variables both in time and in space where is applied; the whole is conditioned by the philosophical traditions in education of each country. We are talking about traditions, the extension of education in years or cycles, the relationship between the philosophical interpretation and the theoretical thought with the school disciplines, the studied literature in these programs, etc.

As we discern from our studies, affinity and place of Philosophy in social culture and in school curricula has a special relationship with democratic development in those societies. Philosophy, logic, literature, linguistics, history and arts, in addition to mathematics, physics, astronomy, biology, chemistry, etc., formed in the nineteenth century a detterente, or better yet, a fund for a scientific and intellectual education. The era of positivism and the advent of technology, strikes harshly the theoretical sciences, but most of all philosophy.

When Europe, in the late ' 30 and early' 40 of the twentieth century was experiencing a great intolerance not only from the crowd but also from the political elites, a thinker, a prominent philosopher, Jacques Maritain will denounce the source of this madness callosity publishing his work entitled "Education at the Crossroads" (Cfr. Maritain, 1943). In the new edition of the work of Maritain (1947 Egloff; 1959 Arthème Fayard; 1969 Nouvelle Edition; etc.), would come out that society and the so-called western civilization are still experiencing the crisis of values that Maritain describes, because the US education system, etc., remain at a crossroads, and education policies in these countries have the main contribution to this crisis. He thinks it was a crisis in the foundation of the system; the human model is in crisis, the model 
of the citizen and citizenship, while it is on the pedestal the citizen designed as workforce and disciplined, professionally capable and in full respect of technical regulations, administrative and judicial (or otherwise known as the name of the state laws). However, in this project, according Maritain, lacks the human component, the development of thought in real size, depth of thought and philosophical meditation, metaphysical or religious dimensions, cosmological and world viewer, spiritual dimensions, ethical and moral, etc. School and education need to change, but the question above implies not just school and education institutions, what is essential, has to do with the aims of education in a society.

As such it has to do with political power, what is it, what relationship seeks to preserve (or sets) with the governed, the people? Education may be issued by the crisis and move towards a new strategy by the political emancipation of the society. Perhaps we should interpret this way the events of 1979 in Paris, as well as remember and reflect on the relationship between philosophy and civilization, humanity and democracy, Jacques Derrida a decade or so later.

Obviously, it suffices to refer to his work entitled "Du droit à la Philosophie" (Right to Philosophy, Derrida, 2002) the first chapter of which is very telling: "Qui a peur de la Philosophie?" (Who's Afraid of Philosophy) published Ed.Galilée, Paris 1990 (Derrida, 1990).

The history of civilizations and the emancipation of human society awake the conscience on the particular role of philosophy in them, the role in conditionality relations and mutual encouragement of philosophy and achievements of democracy. Philosophy is a measure of freedom and its particular achievement, too. This wording in his Hegelian conceptualization must be taken into political dimension, also economic, social, etc. So, it must be taken in the whole human dimension. Many thinkers and scholars see the source of the splendor of Hellenic civilization in the Aegean shores of the Mediterranean, to the flourishing of philosophy there, in the same way is the flourishing philosophy that gave rise to the Roman civilization; we see the source of the power of Chinese civilization, first of all to the Confucian morality, whose foundations are placed in the Confucian philosophy, associated with Buddhism and other ethical, philosophical and religious doctrines. Islamic philosophy gave to Islamic civilization and culture, a particular dimension, as well as Christian philosophy of Reformation and Renaissance gave to European civilization and to the so-called West. The modern theory of democracy, the sovereignty of the people, the doctrine of natural rights and freedoms of man are the main corps of the European Enlightenment and political projects that laid the foundation of modern democracy, in Europe and America. Postmodern philosophy is, for nearly a century, the mind and the project of civilization, its prosperity and democracy. Development strategies of today's society can't be projected simply by technicians; work management and administration can't be done by just the so-called bureaucracy. Philosophy, more than ever before will have a priority. It will be a theoretical foundation and a methodology of study and work, necessary for any particular field of knowledge and activity.

In terms of a developed society with a high level of emancipation, citizen participation acquires new dimensions and new relations with the management and administration of the areas of activity and social values. Existential concerns, cognitive, religious, moral, psychological, educational, etc., to individuals and social subjects should be answered, analyzed and interpreted. To achieve this, there must be a strong theoretical thought, category of philosophical thought, dexterity to penetrate, critical sense, knowledge of the main paradigms, etc. This is a fundamental reason to pay particular attention to the cultivation of the ability to philosophize through pre-university educational programs and undergraduate later. But the relativity of knowledge and thought, diversity and consensus of conflicting views, subjectivity and individuality of thought how will be cultivated to the people? Did we get this through "exact science", subjects such as mathematics, physics, chemistry, biology, astronomy, geography, etc? We are bringing here a consideration of Luc Ferry associated with this problem.

He writes on "exact sciences":

„Not that these don't also provoke disscusions and dissensions.

[...] The very special status of sciences teaching when compared with that of other disciplines is therefore all the more remakable: where education has in general adopted more and more „liberal principles“....... the inculcation of science remains the only one in which the relativism of personal opinion can be neither appreciated nor encouraged.

[...] Like it or not, the solution to a math or physics problem is not a matter individual or majority opinion, and relativism appropriate to other domains disapears in science for the good and simple reason that it presents the last remains of our relation to objectivity. It's in encountering science that the child comes up .......] against a theoritical universe which resists his subjectivity, since it manifest itself to him in a shape of norms that he, at least at his level of learning, cannot contest" (Ferry, L. 1990).

Finally we recall again the historical need for us, Albanians, but not only, to protect a new mind and soul, completely different from previous ideological mind. The need to encourage and develop true human individuality, subjectivity and freedom of thought, can't be satisfied with the cultivation of accounting or manipulative skills, through 
teaching mathematics and other natural sciences, or with the development of logical or algorithmic thinking, or lastly with information and data from these areas. The only way is to educate open minds, critical and reflective one, and for these reasons, we must reevaluate the philosophy.

\section{References}

Breslin, J. F., (1982) "A case for Philosophy in American High School Curriculum" Clearing House, New Jersey.

Derrida, J., (1990) "Du droit à la philosophie" Ed.Galilée, Paris.

Derrida, J. (2002) "Who's Afraid of Philosophy? Right to Philosophy 1", trans. Jan Plug, Stanford University Press, Stanford.

Ferry, L., (1990) "L'invention du gout à l'âge democratique" Ėditions Grasset \& Fasquelle, 1990 (Ferry L., Homo aestheticus: the invention of taste in the democratic age; translated by Robert de Loaiza, The University of Chicago Press, 1993)

Haxhiymeri, A., (2010) "Philosophodicy" Postface to Albanian translation of "What does it all mean?" Thomas Nagel, Mehr Licht, Tirana, p.170.

Jaspers, K., (1954) "Way to Wisdom" Yale University Press, New Heaven \& London.

Maritain, J., (1943) Education at the Crossroads; New Heaven:Yale University Press.

Nagel, Th., (1987) "What Does It All Mean?" Oxford University Press.

Popper K., (1994) "In Search of a Better World: Lectures and essays from thirty years” Roudledge, London („Against big Words“/Wider die großen Worte) Translated by Laura J. Bennett).

The Institute of Curricula and Training (2009) Guidelines for the development of New High school Curriculum; Albania, Tirana. 